\title{
UJI PENGARUH PEMBERIAN PUPUK ORGANIK VERMIWASH DAN PATOGENISITAS PUPUK HAYATI VP3 TERHADAP ENAM BIBIT TANAMAN
}

\author{
Miftahur Rohmah $^{1^{*}}$, Sunawan $^{2}$, Novi Arfarita $^{2^{*}}$ \\ ${ }^{1}$ Mahasiswa S1 Agroteknologi Fakultas Pertanian, Universitas Islam Malang \\ ${ }^{2}$ Dosen Program Studi Agroteknologi, Fakultas Pertanian Universitas Islam \\ Malang JI. MT. Haryono No. 193 Malang 65144, Jawa Timur, Indonesia \\ Korespondensi: noviarfarita@unisma.ac.id
}

\begin{abstract}
Abstrak
Pupuk hayati adalah formula yang berbahan dasar bahan aktif organisme hidup atau laten (mikroba). Formulasi pupuk hayati biasanya berbentuk cair atau padat, mempunyai kemampuan untuk memobilisasi, memfasilitasi dan meningkatkan ketersediaan hara melalui proses biologis yang dari tidak tersedia menjadi bentuk tersedia. Penelitian ini bertujuan untuk mengetahui perbedaan pertumbuhan setelah pemberian vermiwash dan efek patogenisitas pupuk hayati $\mathrm{VP}_{3}$ terhadap enam bibit tanaman: kedelai, kacang panjang, buncis, kangkung, sawi, dan bayam hijau. Penelitian ini dilaksanakan di Laboratorium Mikrobiologi Universitas Islam Malang dari bulan Maret sampai Mei 2020. Penelitian ini menggunakan Rancangan Acak Lengkap dengan 3 perlakuan yang diulang sebanyak 6 kali. Penelitian ini menunjukkan bahwa Inokulasi pupuk hayati VP3 memberikan hasil yang lebih bagus dibandingkan perlakuan lain pada parameter tinggi bibit dan bobot segar bibit tanaman yang diuji cobakan. Namun, pada tanaman kangkung pemberian pupuk hayati VP3 memberikan pengaruh yang nyata hanya pada parameter tinggi bibit dan pemberian pupuk hayati VP3 tidak menunjukkan adanya tanda-tanda patogenesitas seperti nekrosis, layu, busuk akar ataupun busuk batang pada 6 jenis bibit yang diuji cobakan.
\end{abstract}

Kata Kunci : Pupuk hayati VP3, vermiwash, kedelai, kacang panjang, buncis, kangkung, sawi, dan bayam hijau.

\begin{abstract}
Abstrak
Biofertilizer are formulas made from active ingredients of living organisms or latent (microbial), usually in liquid or solid form, have the ability to mobilize, facilitate and increase nutrient availability through biological processes that are not available into available forms. The aims of this research is to determine differences in growth after application of vermiwash and pathogenic effect of VP3 biofertilizer to six plant seeds: soybeans, long beans, chickpeas, kale, mustard greens, and spinach. This research was conducted at the Microbiology Laboratory of Malang Islamic University from March to May 2020. This research uses a Complete Randomized Design (CRD) with 3 treatments and it was repeated 6 times. This research suggests that the treatment of VP3 biofertilizer gave better results compared to other treatments on the parameters of seed height and fresh weight of plant seedlings tested. However, the kale gave a real effect only on seed height parameters and the application of VP3 biofertilizer did not show any signs of pathogenicity such as necrosis, wilting, root rot or stem tot on the six seedlings tested.
\end{abstract}

Keywords : VP3 Biofertilizers, vermiwash, soybeans, long beans, chickpeans, kale, mustard green, spinach

\section{Pendahuluan}

Pupuk hayati adalah formula yang berbahan aktif organisme hidup atau laten (mikroba), biasanya berbentuk cair atau padat, mempunyai kemampuan memfasilitasi memfasilitasi dan meningkatkan ketersediaan hara melalui proses biologis yang dari 
tidak tersedia menjadi bentuk tersedia. Vermiwash digunakan sebagai bahan pembawa dalam proses pembuatan pupuk hayati (Arfarita et al., 2017). Vermiwash ini adalah hasil dari fermentasi pupuk vermikompos dihasilakn dari aktivitas cacing tanah. Arfarita et al., (2016) melakukan isolasi serta identifikasi bakteri fungsional. Dari penelitian tersebut pupuk hayati VP3 (vermiwash+PEG 1\%+tiga isolat bakteri) yang mengandung bakteri indigenus yaitu penambat Nitrogen bebas yaitu Bacillus cereus, kemudian bakteri pelarut $P$ yaitu Pantoea anatis, dan bakteri penghasil senyawa EPS yaitu Pseudomonas plecoglossicida.

Pupuk hayati VP3 yang berbahan dasar vermiwash ini belum diuji cobakan pada perkecambahan tanaman kedelai, kacang panjang, buncis, kangkung, sawi, dan bayam. Apabila suatu benih tidak memiliki kapasitas daya kecambah dan kecepatan berkecambah dengan baik maka akan berpengaruh terhadap pertumbuhan dan hasil produksi tanaman itu sendiri. Dari penelitian sebelumnya diketahui bahwa pupuk hayati vermiwash (VP3) memiliki pengaruh yang baik terhadap produksi tanaman, namun masih belum diketahui hasil terhadap tanaman kedelai, kacang panjang, buncis, kangkung, sawi, dan bayam. Penelitian ini akan menguji pengaruh vermiwash dan patogenisitas pupuk hayati VP3 pada perkecambahan keenam benih di atas.

Vermiwash kaya akan nutrisi terlarut dan asam amino yang mudah tersedia bagi tanaman. Vermiwash bertindak sebagai tonik bagi tanaman dan dengan demikian membantu dalam mengurangi jamur patogen tanaman. Selain itu juga dapat meningkatkan laju fotosintesis pada tanaman serta meningkatkan jumlah mikroorganisme di dalam tanah yang mana mikroorganisme ini membantu dalam proses dekomposisi bahan organik tanah (Tripathi et al., 2005). Penelitian ini bertujuan untuk mengetahui pengaruh pemberian vermiwash dan (sifat patogen) pupuk hayati VP3 terhadap enam bibit tanaman.

\section{Bahan dan Metode}

Penelitian dilakukan selama 3 bulan terhitung mulai bulan Maret sampai bulan Mei 2020. Penelitian dilaksanakan di Ruang Mikrobiologi, Laboratorium Pusat dan Halal Center Universitas Islam Malang.

Alat yang digunakan meliputi test tube, rak test tube, gelas ukur, wrapping plastic, alumunium foil, autoclave, beajer glass, petri dish, micropipette, mikrotip biru dan kuning steril, penggaris, jangka sorong, dan timbangan digital. Sedangkan bahan yang digunakan adalah kapas, benih kedelai, kacang panjang, buncis, kangkung, sawi, bayam, aquadest, formulasi cair pupuk hayati VP3 dan larutan Yoshida.

Rancangan penelitian yang digunakan adalah Rancangan Acak Lengkap (RAL) 
yang terdiri dari 3 perlakuan yaitu K0: Aquadest Steril; V0: Vermiwash Steril; VP3: vermiwash+PEG 1\%+tiga isolat bakteri semua perlakuan diulang sebanyak 6 kali sehingga diperoleh 18 perlakuan.

Variabel yang diamati meliputi variabel pertumbuhan yaitu tinggi tanaman, panjang akar dan bobot segar dan tanda-tanda patogenisitas seperti layu, nekrosis, busuk akar dan busuk batang.

Data yang didapat kemudian dianalisa menggunakan analisis statistik dengan uji $F$ (ANOVA) taraf $5 \%$ serta jika memberikan hasil yang nyata, maka dilanjutkan dengan uji BNT taraf 5\%.

\section{Hasil dan Pembahasan}

\section{Uji Patogenisitas}

Berdasarkan hasil penelitian (Tabel 1), dapat diketahui bahwa perlakuan pupuk hayati VP3 tidak menunjukkan adanya tanda-tanda patogenisitas seperti layu, nekrosis, busuk akar maupun busuk batang pada enam bibit yang diuji cobakan: kedelai, kacang panjang, buncis, kangkung, sawi, dan bayam hijau.

Hal ini menunjukkan bahwa pemberian pupuk hayati VP3 yang mengandung tiga isolat bakteri indegenus seperti penambat N-bebas (Non Simbiotik) yaitu Bacillus cereus, bakteri pelarut $\mathrm{P}$ (Pantoea anatis), dan bakteri penghasil eksopolisakarida (Pseudomonas plecoglossicida) berperan sebagai agensia biokontrol pengendali hayati. Bakteri yang berperan dalam pupuk hayati VP3 adalah bakteri penambat $\mathrm{N}$ bebas (Bacillus cereus). Selain sebagai bakteri penambat $N$ bakteri ini merupakan salah satu agensia patogen yang mempunyai potensi besar untuk digunakan sebagai pengendali hayati. Hal ini sesuai pendapat (Emmert dan Handelsman 2006) bahwa $B$. cereus dapat menghasilkan dua macam senyawa antibiotik yang dapat menghambat pertumbuhan jamur Phytophthora penyebab rebah kecambah dan busuk akar pada tanaman kedelai.

P. ananatis dilaporkan menghasilkan indol-3asetat asam (Enya et al., 2007) yang dapat berperan dalam patogenesis. Selain itu, bakteri $P$. ananatis mengambil peranan sebagai pelarut fosfor.

Pemberian Pupuk hayati perangsang pertumbuhan dan agensia pengendali hayati (biocontrol) mengandung mikroba yang dapat mendorong pertumbuhan tanaman serta melindungi sistem perakaran tanaman sehingga dapat meningkatkan daya tahan tanaman terhadap serangan penyakit (Suwahyono, 2011). Pseudomonas sp. dapat menstimulasi munculnya daya tahan tanaman dari serangan infeksi jamur penyebab penyakit pada akar, virus serta bakteri (Van Peer et al., 1991; Wei et al., 1994; Zhou et 
al., 1992; Alstrom 1991).

Arancon et al., (2006) menyatakan bahwa mikroba tanah mengambil peranan penting dalam ketersediaan hara dan daur ulang nutrisi di dalam tanah serta kemampuan penyimpanan unsur hara dalam tanah. Efektifitas agen hayati dipengaruhi oleh faktor strain mikroba yang ada didalamnya, lingkungan tumbuh dan genotip tanaman.

Bahan pembawa dari pupuk hayati menjadi faktor penentu keberhasilan di dalam penggunaan pupuk hayati sebab memiliki peran untuk menjaga efektivitas serta viabilitas mikroba yang terkandung. Saat inokulasi mikroba dilakukan ke rhizosfir maka akan memberikan dampak positif serta negatif atau dapat juga tidak memberikan dampak apapun (Wuriesyliane et al., 2013).

Tabel 1. Pengaruh Perlakuan terhadap Gejala Sakit pada Enam Bibit Tanaman

\begin{tabular}{|c|c|c|c|c|c|c|c|c|c|c|c|c|}
\hline \multirow{2}{*}{ Perlakuan } & \multicolumn{4}{|c|}{ Kedelai } & \multicolumn{4}{|c|}{ Kacang $P$. } & \multicolumn{4}{|c|}{ Buncis } \\
\hline & NK & L & $\mathrm{BA}$ & BB & NK & $\mathrm{L}$ & $\mathrm{BA}$ & $\mathrm{BB}$ & NK & $\mathrm{L}$ & $\mathrm{BA}$ & $\mathrm{BB}$ \\
\hline $\mathrm{K} 0$ & - & - & - & - & - & - & - & - & - & - & - & - \\
\hline V0 & - & - & - & - & - & - & - & - & - & - & - & - \\
\hline VP3 & - & - & - & - & - & - & - & - & - & - & - & - \\
\hline \multirow{2}{*}{ Perlakuan } & \multicolumn{4}{|c|}{ Kangkung } & \multicolumn{4}{|c|}{ Sawi } & \multicolumn{4}{|c|}{ Bayam Hijau } \\
\hline & NK & L & $\mathrm{BA}$ & BB & NK & $\mathrm{L}$ & $\mathrm{BA}$ & $\mathrm{BB}$ & NK & $\mathrm{L}$ & $\mathrm{BA}$ & $\mathrm{BB}$ \\
\hline $\mathrm{K} 0$ & - & - & - & - & - & - & - & - & - & - & - & - \\
\hline v0 & - & - & - & - & - & - & - & - & - & - & - & - \\
\hline VP3 & - & - & - & - & - & - & - & - & - & - & - & - \\
\hline
\end{tabular}

Keterangan: NK: Nelrosis, L: Layu, BA: Busuk Akar, BB: Busuk Batang; (-) tidak ada patogenisitas (+) ada patogenisitas.

\section{Pertumbuhan Enam Bibit Tanaman}

Tabel 2 menunjukkan bahwa pemberian pupuk hayati VP3 pada bibit kedelai, buncis, kangkung, dan sawi memberikan pengaruh yang sama atau tidak berbeda nyata dengan perlakuan V0 (vermiwash), namun memberikan pengaruh yang berbeda nyata dengan KO (kontrol). Sedang pada parameter panjang akar semua perlakuan memberikan efek yang sama/tidak berbeda nyata. 
Tabel 2. Pengaruh Perlakuan pada Pertumbuhan Enam Bibit Tanaman

\begin{tabular}{|c|c|c|c|c|c|c|c|c|c|}
\hline \multirow{2}{*}{ Perlakuan } & \multicolumn{3}{|c|}{ Kedelai (5 hst) } & \multicolumn{3}{c|}{ Kacang P. (5 hst) } & \multicolumn{3}{c|}{ Buncis (3 hst) } \\
\cline { 2 - 13 } & TT & PA & BB & TT & PA & BB & TT & PA & BB \\
\hline K0 & $5.333 \mathrm{a}$ & 2.350 & $0.620 \mathrm{a}$ & $3.367 \mathrm{a}$ & $2.037 \mathrm{a}$ & $0.570 \mathrm{a}$ & $7.100 \mathrm{a}$ & 3.683 & $0.808 \mathrm{a}$ \\
\hline V0 & $9.400 \mathrm{~b}$ & 2.767 & $0.863 \mathrm{~b}$ & $6.450 \mathrm{~b}$ & $1.950 \mathrm{a}$ & $0.677 \mathrm{a}$ & $9.783 \mathrm{~b}$ & 4.867 & $1.022 \mathrm{~b}$ \\
\hdashline VP3 & $7.817 \mathrm{~b}$ & 3.750 & $0.715 \mathrm{~b}$ & $8.817 \mathrm{c}$ & $4.133 \mathrm{~b}$ & $0.860 \mathrm{~b}$ & $10.500 \mathrm{~b}$ & 5.133 & $1.132 \mathrm{~b}$ \\
\hline BNT 5\% & 1.744 & TN & 0.114 & 2.045 & 1.415 & 0.187 & 1.301 & TN & 0.127 \\
\hline \multirow{2}{*}{ Perlakuan } & \multicolumn{1}{|c|}{ Kangkung (5 hst) } & & Sawi (8 hst) & & Bayam Hijau (12 hst) \\
\hline K0 & TT & PA & BB & TT & PA & BB & TT & PA & BB \\
\hline V0 & $7.467 \mathrm{a}$ & 1.767 & 0.243 & $4.467 \mathrm{a}$ & 1.233 & $0.043 \mathrm{a}$ & $2.300 \mathrm{a}$ & $1.100 \mathrm{~b}$ & $0.004 \mathrm{a}$ \\
\hline VP3 & $7.550 \mathrm{~b}$ & 1.983 & 0.273 & $5.067 \mathrm{ab}$ & 1.333 & $0.055 \mathrm{~b}$ & $2.383 \mathrm{a}$ & $0.950 \mathrm{a}$ & $0.005 \mathrm{a}$ \\
\hline BNT 5\% & 0.750 & 0.293 & $5.650 \mathrm{~b}$ & 1.383 & $0.060 \mathrm{~b}$ & $2.667 \mathrm{~b}$ & 1.133 & $0.007 \mathrm{~b}$ \\
\hline
\end{tabular}

Keterangan: Angka-angka yang didampingi huruf yang sama pada kolom yang sama menunjukkan tidak berbeda nyata pada Uji BNT 5\%; N: Nyata; TT: Tinggi Tanaman; PA: Panjang Akar; dan BS: Bobot Basah.

Pemberian formulasi cair pupuk hayati VP3 pada kacang panjang memberikan pengaruh yang berbeda nyata dibanding perlakuan lain pada semua parameter pengamatan. Pada bayam hijau pemberian pupuk hayati VP3 memberiakan hasil yang berbeda nyata dengan semua perlakuan pada parameter tinggi bibit dan bobot segar. Namun, pada parameter panjang akar pemberian pupuk hayati VP3 memberikan hasil yang tidak berbeda nyata dengan kontrol dan V0 sedang $\mathrm{V} O$ berbeda nyata dengan KO.

Lakitan (2004) menyatakan bahwa unsur hara yang paling berpengaruh terhadap pertumbuhan dan perkembangan tanaman ialah unsur N. Hal ini juga menunjukkan bahwa pupuk hayati VP3 dengan bahan pembawa vermiwash memberikan pengaruh yang baik dalam meningkatkan pertumbuhan tinggi dan bobot segar tanaman. Hal ini sesuai pendapat Fahrudin (2009), yang menyatakan bahwa kotoran cacing mengandung zat pengatur tumbuh (ZPT) seperti giberelin, sitokinin, dan auksin, serta unsur hara makro N,P, K, Mg, dan Ca.

Auksin adalah hormone tumbuhan yang mengandung senyawa indoleacetic acid (IAA), serta beberapa senyawa lain. Hormon indoleacetic acid mempunyai sifat mudah diserap oleh tanaman sebab mudah terurai oleh senyawa konjugat berupa IAA oksidase yang dihasilkan oleh tumbuhan sendiri. Auksin disintesis di meristem apical akar dan daun-daun muda (Hartmann, 2001).

Werner et al., (2001), bahwa sitokinin bersamaan dengan auksin memiliki peranan penting dalam menstimulasi terjadinya diferensiasi jaringan tertentu (pembentukan 
tunas dan pertumbuhan akar) serta pembelahan sel.

Pada parameter tinggi bibit, panjang akar, dan bobot segar pemberian formulasi cair pupuk hayati VP3 memberikan hasil yang baik dibandingkan perlakuan lain. Menurut Meirina (2011), unsur hara yang dihasilkan oleh aktivitas mikroba yang terkandung didalam biofertilizer berupa nitrogen $(N)$, fosfor $(P)$, dan kalium $(K)$ akan diserap oleh tanaman untuk proses metabolisme didalam tanaman. Pupuk hayati VP3 yang mengandung bakteri penambat $\mathrm{N}$-free, pelarut fosfor, dan bakteri penghasil Eksopoli sakarida mampu menyediakan nutrisi tambahan secara berkala. Proses fotosintesis yang optimal akan berpengaruh terhadap bobot segar tanaman. Kondisi air yang tersedia akan lebih mudah diserap oleh tanaman sehigga secara otomatis kadar air pada tanaman akan meningkat sehingga berat segar tanaman menjadi bertambah (Sudjana, 2013).

Dalam penelitian ini pemberian pupuk hayati VP3 memberikan pertumbuhan tanaman buncis (Phaseolus vulgaris L.) yang berbeda nyata pada parameter tinggi bibit dan bobot segar (Tabel 2.). Hal tersebut sesuai pernyataan (Brady dan Buckman, 1983) bahwa pelepasan hara seperti Nitrogen, Phospor dan Kalium yang dibutuhkan oleh tanaman terjadi secara bersamaan dengan psoses perombakan bahan organik yang dilakukan oleh mikroorganisme. Sehingga saat tanaman membutuhkan hara, hara tersebut sudah tersedia bersamaan dengan perombakan bahan organik oleh mikroba.

Pada parameter panjang akar (Tabel 2.) kedelai, buncis, kangkung, dan sawi masing-masing perlakuan memberikan hasil yang sama/tidak berbeda nyata. Masfufah, A (2012) menyatakan apabila tanaman ditempatkan pada kondisi unsur hara yang sesuai maka tanaman mengalami pertumbuhan ke atas sehingga menjadi lebih tinggi. Sebaliknya, apabila tanaman ditempatkan dalam kondisi ketersediaan unsur hara yang berlebihan akan mengakibatkan tanaman enggan menyerap karena nutrisi sudah tersedia di daerah perakaran sehingga mengakibatkan rendahnya panjang akar.

Selain itu, penghambatan pertumbuhan akar dapat disebabkan oleh etilen yang terbentuk dari adanya produksi auksin dan sebagian besar etilen pada tanaman dapat menghambat pemanjangan akar (Syaiful et al., 2012). Auksin disentesis di ujung tajuk dan pangkal akar kemudian ditranslokasikan melalui proses embrio. Dalam penelitian ini bibit diuji cobakan ke dalam test tube (gelas kaca) transparan yang ditutup menggunakan kapas sehingga akar bibit tanaman uji terkena cahaya matahari secara langsung dan kemungkinan besar mengalami kerusakan. Hal ini sesuai dengan Riyadi (2014) yang menyatakan bahwa Auksin mempunyai karakter mudah rusak apabila 
terkena cahaya secara langsung.

Penelitian yang di lakukan Zimmerman dan Wilcoxon (1953) dalam Anonymous (2011), menyebutkan bahwa dari penelitian-penelitian terdahulu bahwa auksin mempunyai peranan dalam pembentukan akar adventif (ujung akar). Tetapi dalam penggunaannya dibutuhkan konsentrasi yang tepat agar diperoleh perakaran yang optimal. Konsentrasi yang diberikan pada masing-masing perlakuan sama yaitu sebesar $200 \mu \mathrm{l}$ sehingga jumlah konsentrasi tersebut tidak memberikan pengaruh terhadap rendahnya akar yang tidak berbeda nyata pada perlakuan kontrol, $\mathrm{VO}$, dan VP3.

\section{Kesimpulan dan Saran}

Inokulasi formulasi cair pupuk hayati VP3 memberikan hasil yang lebih baik dibandingkan perlakuan lain pada parameter tinggi bibit dan bobot segar bibit tanaman yang diuji cobakan. Namun, pada tanaman kangkung pemberian pupuk hayati VP3 memberikan pengaruh yang nyata hanya pada parameter tinggi bibit. Inokulasi pupuk hayati VP3 tidak menunjukkan adanya tanda-tanda patogenesitas seperti nekrosis, layu, busuk akar ataupun busuk batang pada 6 jenis bibit yang diuji cobakan.

Dari hasil penelitian ini disarankan Vermiwash sebagai bahan pembawa dalam pupuk hayati VP3 dengan penambahan 3 isolat bakteri kemungkinan mengandung hormon IAA. Perlu dilakukan uji lanjut mengenai kandungan zat pengatur tumbuh (fitohormon) IAA dalam formulasi cair pupuk hayati VP3 dan uji VP3 dilapang pada bayam, kangkung, dan sawi. VP3 potensial sebagai Seed Treatment karena tidak bersifat patogen terhadap bibit tanaman uji dan juga diketahui mengandung bakteri agen pengendali penyakit tular tanah.

\section{Daftar Pustaka}

Alstrom, S. 1991. Incudtion of disease resistence in comman bean susceptible to halo bloght bacterial pathogen after seed bacterization with rhizospere pseudomonads. J. Gen. Appla. Mivrobiol. 37: 495-501.

Arancon, N. Q., Edwards, C.A., and Bierman, P. 2006. Influence of Vermicompost on Field Strawberries: Part 2. Effects on Soil Microbigical and Chemical Properties. Bioresource Technol., 97, 831-840.

Arfarita, N., Hidayati, N., Rosyidah, A., Machfudz, M. and Higuchi, T. 2016. Exploration of Indigenous Soil Bacteria Producing-Exopolysaccharides for Stabilizing of Aggregates Land Potential as Biofertilizer. Journal of Degraded and Mining Lands Management, 4(1): 697-702.

Arfarita, N., Lestari, M.W., Murwani, I. and Higuchi, T. 2017. Isolation of Indigenous Phosphate Solubilizing Bacteria from Green Bean Rhizospheres. Journal of Degraded and Mining Lands Management, 4(3): 845-851. 
Brady, N.C., and H. O. Buckman. 1983. The Nature and Properties of Soils. Macmillan Publishing Co., Inc, New Delhi.

Emmert, EAB \& Handelsman, Jo 2006, Biocontrol of plant disease: a (Gram-) positive perspective, FEMS Microbiology Letters 171:1-9.

Enya, J., Shinohara, H., Yoshida, S., Tsukiboshi, T., Negishi, H., Suyama, K. and Tsushima, S. (2007) Culturable leaf-associated bacteria on tomato plants and their potential as biological control agents. Microb. Ecol. 53, 524-436.

Fahrudin, F. 2009. Budidaya Caisim (Brasica juncea) Menggunakan Ekstrak Teh dan Pupuk Kascing. Skripsi. Fakultas Pertanian Universitas Sebelas Maret, Surakarta.

Hartman, H.T., Kester, D.E., Davies Jr \& Geneve. 2001. Plant Propagation Principles and Practices. New York: Pearson.

Lakitan, B. 2004. Dasar-Dasar Fisiologi Tumbuhan. PT. Raja Grafindo Persada. Jakarta.

Masfufah, A. 2012. Pengaruh Pemberian Pupuk Hayati (Biofertilizer) Pada Berbagai Dosis Pupuk dan Media Tanam yang Berbeda Terhadap Pertumbuhan dan Produksi Tanaman Tomat (Lycopersicum esculentum) pada Polybag. Skripsi. Universitas Airlangga. Surabaya.

Meirina, T., Darmanti, S., dan Haryanti, S., 2011, Produktivitas Kedelai (Glycine max (L) Merril var. lokon) yang diperlakukan dengan Pupuk Organik Cair Lengkap pada Dosis dan Waktu Pemupukan yang Berbeda, Skripsi, Jurusan Biologi MIPA, Universitas Diponegoro, Semarang.

Sudjana, Briljan. Winda Rianti. Muharam. 2013. Perubahan Unsur Hara Makro C, N, P, $\mathrm{K}$ dan $\mathrm{C} / \mathrm{N}$ Rasio Tanah Salin Karawang Akibat Pemberian Bokasi Jerami dan Fungsi Mikoriza arbeskula (FMA)Serta Pengaruhnya Terhadap Pertumbuhan dan Hasil Tanaman Kedelai (Glycine max). Jurnal IImu Pertanian dan Perikanan. Vol 2 (2): 109-119.

Suwahyono, U. 2011. Petunjuk praktis penggunaan pupuk organik secara efektif dan efisien. Penebar Swadaya. 2011. Jakarta. $124 \mathrm{hlm}$.

Syaiful, S.A., Amin, M.I., Novaty, E., Dungga \& Riadi, M. 2012. Peran ConditioningBenih Dalam Meningkatkan Daya Adaptasi Tanaman Kedelai Terhadap Stres Kekeringan. Universitas Hasanudin. Makasar.

Tripathi, N. K., K. S. Latimer, C.R. Gregory, B. W. Ritchie, R.E. Wooley, and R. L. Walker. 2005. Development and evaluation of an experimental model of cutaneous columnaris disease in koi carp (Cyprinus carpio). J. Vet. Diag. invest. 17:45-54.

Van Peer, R., GJ. Niemann and B. Schippers. 1991. Induced resistance and phytoalexin accumulation in biological control of Fusarium wilt of carnation by Pseudomonas sp. Strain WCS4175. Phytopatology 81: 728-734.

Wei, G., Kloepper, J.W., \& Tuzun, S. 1991, Induction of systemic resistance of cucuumber to Colletotrichum orbiclilare by select strain of rhizobacteria.Phytopathology. 81: 1508-1512. 
Werner, T., Motyka, V., Strnad, M and T Schmulling. 2001. Regulat lon of Plant Growth by Cytokinin. USA.

Wuriesyliane, Nuni G., A. Madjid, Hary W., dan Nih L.P.SR. 2013. Pertumbuhan dan Hasil Padi pada Iceptisol Asal Rawa Lebak yang Diinokulasi Berbaagi Konsorsium Bakteri Penyumbang Unsur Hara. Jurnal Lahan Suboptimal. Vol.2, No. 1ISSN: 2302-3015.

Zhou, T ., Rankm, L. \& Paulitz, T. C. 1992. Induced resistance in the biological control of Pythium aphanidermatum by Pseudomonas spp. On European cucumber. (Abstr.) 